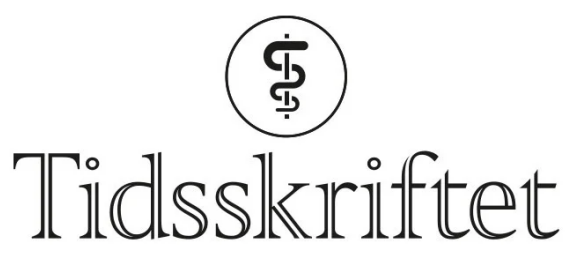

DEN NORSKE LEGEFORENING

\title{
Hvorfor får ikke alle type 2-diabetes?
}

KRONIKK

\section{TROND METHI}

Trond Methi (f. 1977) er farmasøyt, ph.d. og arbeider som medisinsk rådgiver i Lilly Diabetes. Forfatter har fylt ut ICMJE-skjemaet og oppgir følgende interessekonflikter: Han er ansatt i Eli Lilly. Email: methi.trond@gmail.com

\section{PER MEDBØE THORSBY}

Per Medbøe Thorsby (f. 1964) er ph.d., seksjonsoverlege og medisinsk ansvarlig ved Hormonlaboratoriet, Oslo universitetssykehus.

Forfatter har fylt ut ICMJE-skjemaet og følgende interessekonflikter: Han har mottatt forelesningshonorar fra Siemens, Novo Nordisk, Bristol-Myers Squibb, Norges diabetesforbund og Sanofi.

Tusenvis av gener styrer vår metabolisme, og type 2-diabetes er derfor blitt kalt genetikerens mareritt. Genetiske assosiasjonsstudier har ikke gitt det resultatet man håpet på, nemlig å avdekke mekanismene som ligger til grunn for utviklingen av fedme og diabetes. Likevel er genetiske og epigenetiske teorier viktige for forståelsen av fedme- og diabetesepidemiene. 


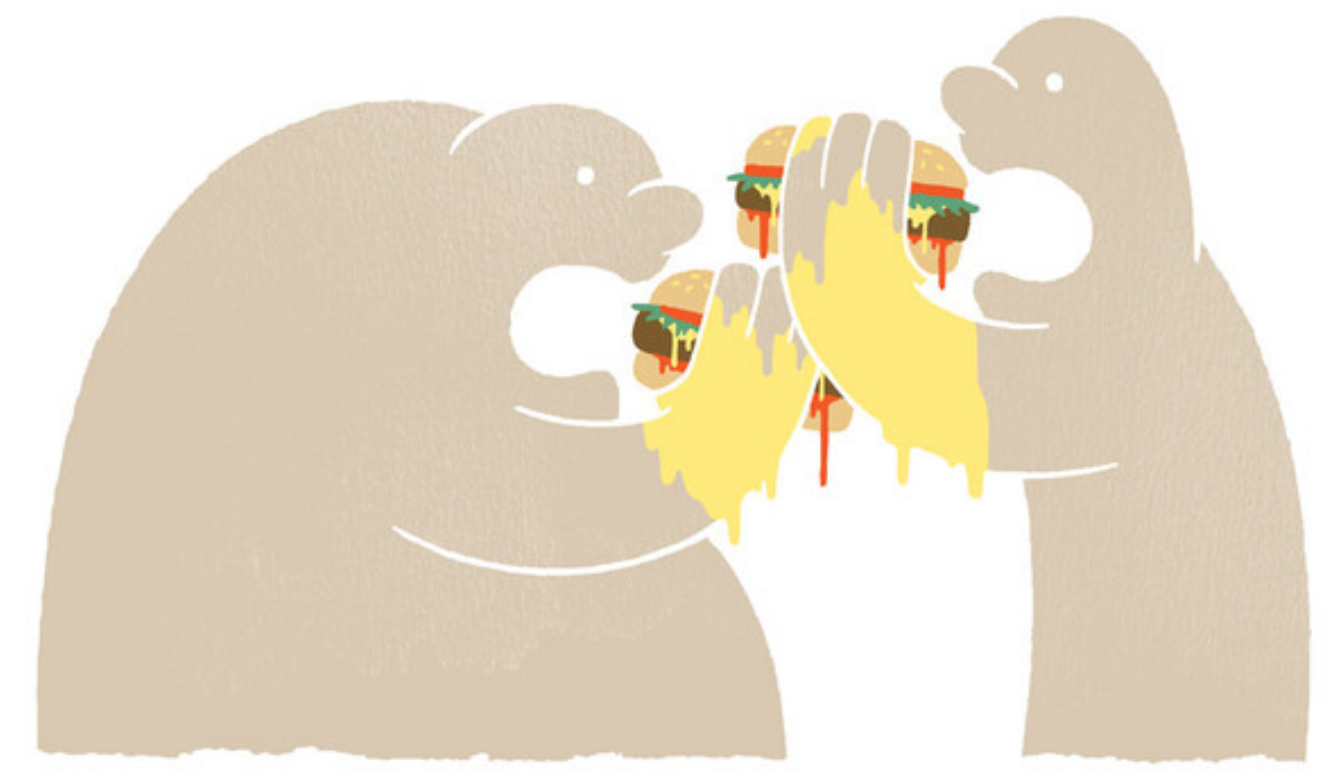

Illustrasjon @ Superpop

I 1962 stilte den amerikanske genetikeren James Neel (1915-2000) et fundamentalt spørsmål: Hvorfor er antatte gener som disponerer for fedme og type 2-diabetes så prevalente i befolkningen? (1). Dette er tilstander som øker morbiditet og mortalitet, og nedsetter fruktbarheten, og som dermed ikke er forenlige med positiv genetisk seleksjon. Neels løsning var en enkel og intuitiv hypotese om nøysomme gener (thrifty genes) som disponerer for $\emptyset \mathrm{kt}$ fettlagring i gode tider og som er blitt selektert frem gjennom gjentatte sykluser med hungersnød i menneskehetens historie. Dagens situasjon med fedme og type 2-diabetes er resultatet av misforholdet mellom det som var en gunstig adapsjon for våre forfedre og det nåværende overflodssamfunnet uten hungersnød.

\section{«Drifty genotype»}

Den britiske biologen Thomas Huxley (1825-95) har uttalt at enhver «vakker hypotese kan ødelegges av en stygg sannhet» (2). Hvis fettlagring har vært så gunstig gjennom historien, hvorfor er ikke alle i den vestlige verden fete? Matematiske modelleringer viser at det antakelig har vært nok hungersnøder til at nøysomme fedmeinduserende gener burde vært fiksert i hele befolkningen (3). Alle som lever under vestlig livsstil er dog ikke fete, og dermed vakler hypotesen, eller forteller ikke hele sannheten. Selv i USA, den vestlige livsstils vugge, er fortsatt en tredel av befolkningen normalvektige. Gitt den ubegrensede tilgjengeligheten på kaloririk mat og muligheten for å leve et liv uten nevneverdig fysisk aktivitet, er dette minst like oppsiktsvekkende som den fete tredelen i den motsatte enden av skalaen.

Den britiske biologen John Speakman har lansert en alternativ forklaring: «the drifty genotype». Han argumenterer med at fettlagring riktignok forlenger overlevelsen ved hungersnød, men at den også nedsetter mobiliteten og dermed evnen til å unnslippe rovdyr og fiender samt forflytte seg til nye jaktmarker (4). Ifølge Speakman er fedme resultatet når denne negative seleksjonen opphører, dvs. at nedsatt mobilitet ikke lenger er en begrensende faktor. Dette skjedde da vi oppdaget ild, lagde våpen og organiserte oss i jordbrukssamfunn. I moderne tid kan vi forlenge dette og dermed forsterke fedmeeffekten med introduksjonen av matbutikker, vann i springen, oppvarmede hus, TV, bil og stillesittende kontorarbeid. 
Ser man på andre arter som lever vilt, er fraværet av fedme påtakelig. Dette begrenses av mattilgangen, og mange arter vil spise seg fete hvis de bare får muligheten, men ikke alle. Enkelte prioriterer lagring av energi i depoter utenfor kroppen og bevarer dermed livsviktig mobilitet. Det er interessant nok en omvendt korrelasjon mellom hjernestørrelse og fettmasse over et bredt spekter av dyr i naturen (5). Stor fett masse samsvarer med en mindre hjerne, og vice versa. Lagring av energi på kroppen og lagring av informasjon i hjernen kan dermed være alternative strategier for å takle livets usikkerhet. Mennesket faller riktignok utenfor; vi har både har store hjerner og store fettdepoter.

\section{Gener, betaceller og insulinresistens}

Neel erkjente at hypotesen om nøysomme gener var problematisk. Ingen nøysomme gener som oppfyller kriteriene er blitt oppdaget, og med Neels egne ord er «type 2-diabetes genetikerens mareritt» (ㅁ). Vår metabolisme styres ikke av noen få enkeltgener, men et nettverk av mange tusen der små effektstørrelser adderes opp til organismens totale biokjemiske fenotype. Det er ikke uten grunn at fedme- og diabetesforskningen har vært mager på resultater fra genetiske assosiasjonsstudier. Faktisk har jakten på gener som predisponerer for fedme druknet i den vestlige verdens fedmeepidemi, og nå er det mer fruktbart å lete etter det motsatte: gener som fremmer slankhet.

Et sekstitalls gener som predisponerer for type 2-diabetes har riktignok blitt identifisert, men de forklarer totalt sett bare noen prosent av den arvelige risikoen vi vet er forbundet med sykdommen. Interessant nok virker betacellen å være hovedpunktet for genetisk disposisjon for type 2-diabetes, mens insulinresistens har gitt færre treff.

Obduksjonsstudier har vist at personer med type 2-diabetes har betydelig redusert betacellevolum sammenliknet med friske kontrollpersoner, mens normoglykemiske fete personer har økt betacellevolum i forhold til slanke (7.). Noen er altså i stand til å kompensere på betacellenivå for å håndtere kaloripåtrykket, mens andre svikter, og det er antakelig betacellesvikten som gir opphavet til den metabolske kollapsen som karakteriserer type 2-diabetes. Insulinresistens er på sin side kanskje den naturlige konsekvensen av ethvert kronisk kalorioverskudd, der cellen prøver å beskytte seg selv mot oksidativt stress og kaloriforgiftning ( $\underline{8}$ ). Det er ukjent hvorfor noen har betaceller som ikke makter vestlig livsstil, mens andre klarer å kompensere, men kanskje vi kan finne noen spor i Finnmark i 1960- og 70-årene?

\section{«Thrifty phenotype»}

I 1986 publiserte den britiske legen og epidemiologen David Barker (1938-2013) en studie fra Storbritannia som viste en sammenheng mellom spedbarnsdødelighet og hjertesykdom i voksen alder (9.). Ifølge Barkers hypotese svekkes organutviklingen av et lavkalorisk fosterliv, hvilket gir seg utslag i økt risiko for kroniske sykdommer i voksen alder, spesielt hvis kaloritilgangen er for høy. Interessant nok observerte den norske legen

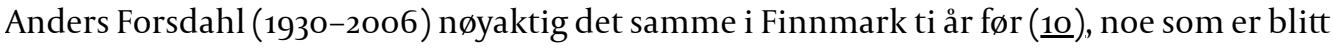
glimrende oppsummert i Tidsskriftet tidligere (11). Barkers «developmental origins of chronic disease», eller "thrifty phenotype», har fătt stort gehør, og han fulgte opp med studier i 1990-årene som viste at lav fødselsvekt var forbundet med økt risiko for type 2diabetes i voksen alder (12, 13$)$. Tilsvarende data er blitt reprodusert flere steder i verden, bl.a. i Danmark hvor man har sett at fedme og type 2-diabetes hos den ene i et monozygotisk tvillingpar har sammenheng med lavere fødselsvekt (14.). Dette er interessant, ettersom disse har identisk genetikk og er blitt fostret opp i samme miljø. Ulik 
blodtilførsel og næringstilgang gjennom placenta kan forklare diskrepansen i fødselsvekt og svekkelsen i organutvikling hos den ene, som i sin tur predisponerer for sykdom til tross for like gener.

\section{«Thrifty epigenotype»}

I de senere årene har man lansert teorier om en epigenetisk reprogrammering av fosteret. Det vil si at man kan ha de samme genene og ikke behov for langsom genetisk evolusjon à la Neel, men ulik miljøpåvirket regulering av gentranskripsjonen, som så gir opphav til ulike fenotyper. Epigenetikeren Reinhard Stöger kaller det «the thrifty epigenotype» (15). I henhold til dette konseptet blir barnets metabolisme programmert av kaloritilgangen intrauterint, og man kan eksempelvis tilpasses til å skulle leve i en lavkaloriverden. Det som predisponerer for metabolsk sykdom er egentlig en nyttig adapsjon, og ikke en patologisk tilstand, og fedme/type 2-diabetes er bare resultatet hvis det er et misforhold mellom det intrauterine og det reelle miljøet man blir født inn i.

Data fra den nederlandske hungersvinteren som fant sted mot slutten av annen verdenskrig understøtter denne teorien. Der så man at barn som opplevde kalorirestriksjon i mors liv, med påfølgende kaloririkdom etter frigjøringen, i større grad

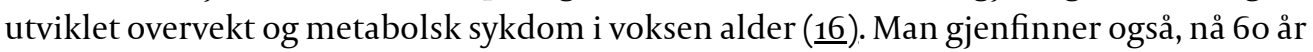
senere, epigenetiske forskjeller mellom hungersnødkohorten og kontrollpersoner født på samme tid uten hungersnød (17.). Dette epigenetiske fingeravtrykket ser også ut til å videreføres til neste generasjon (묘).

\section{«Maladaptiv hypotese»}

En annen mulighet er at fedme aldri har vært en evolusjonistisk fordel, men heller er biproduktet av en annen genetisk seleksjon, altså en maladapsjon (19).

Varmeproduserende brunt fettvev er en interessant kandidat i så måte. Man har lenge vært klar over at også voksne, ikke bare nyfødte, har brunt fettvev. Dette ble "gjenoppdaget» i 2009 i to artikler som så nærmere på prevalens av og kuldeindusert aktivitet i brunt fettvev hos voksne $(\underline{\underline{20}}, \underline{21})$. Det brune fettvevet spiller en rolle i kroppens totale energiforbrenning, og det er stor variasjon fra person til person. Videre er det en sammenheng mellom lave nivåer av brunt fettvev og høy kroppsmasseindeks (samt dårligere glykemisk kontroll). I et slikt perspektiv kan man se for seg at de som gjennom evolusjonen har hatt mindre behov for varmeproduksjon har mindre brunt fettvev. De har større risiko for fedme og metabolsk sykdom fordi de i mindre grad evner å forbrenne sine overskuddskalorier i form av varme. Dette kan forklare den lavere prevalensen av type 2-

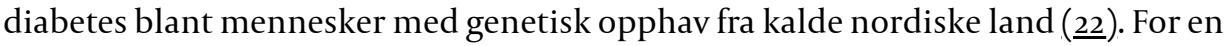
oversikt over ulike teorier se ramme 1.

\section{RAMME 1}

\section{Teorier rundt genetisk utslag på fedme og type 2-diabetes}

- Thrifty genotype (James Neel): Fedme og type 2-diabetes er resultatet av en positiv genetisk seleksjon for fettlagring for å overleve hungersnøder. Dette går galt med vestlig livsstil der hungersnøden aldri kommer (1)

- Drifty genotype (John Speakman): Fedme og type 2-diabetes er resultatet av opphør av negativ seleksjon, eksempelvis lavere behov for mobilitet for å unnslippe rovdyr/fiender (4) 
- Thrifty phenotype (David Barker): Fedme og type 2-diabetes er resultatet av et misforhold mellom et kalorifattig fosterliv, med svekket organutvikling, og påfølgende overflod (12)

- Thrifty epigenotype (Reinhard Stöger): Den nøysomme fenotype er resultatet av en adaptiv epigenetisk betinget reprogrammering i fosterlivet for å tilpasse individet til å leve i en kalorifattig verden (15)

- Genetisk maladapsjon (John Speakman): Fedme er ikke en evolusjonistisk fordel, men biproduktet av annen genetisk seleksjon, for eksempel ulike nivåer av brunt fettvev som følge av ulike behov for varmeproduksjon (19)

\section{Både jordbrukere og jegere}

En nøysom kaloribesparende reprogrammering av organismen kan bestå av mange elementer: Redusert forbrenning/økt inaktivitet, økt appetitt når mat er tilgjengelig, mer følsomme betaceller og $\emptyset \mathrm{kt}$ evne til fettlagring. Hvorvidt disse mekanismene er adaptive epigenetisk regulerte tilpasninger til en lavkaloriverden, og hvordan dette ev. manifesterer seg cellebiologisk, fysiologisk og patologisk, er fortsatt på hypotesestadiet. Tilsvarende er det ukjent i hvilken grad disse årsakene kan forklare dagens diabetesprevalens. Evolusjonsbiologen Jared Diamond påpeker at diabetesprevalensen øker kraftig mange steder i verden, og at dette spesielt gjelder befolkningsgrupper som brått har gått fra en tradisjonell rural lavkalorilivsstil til vestlig urban høykaloritilværelse (203). Dette gjelder pimaindianerne i Arizona, aboriginere i Australia, stillehavsøybeboere (eksempelvis Nauru) samt flere befolkninger i Afrika, Midt- $\emptyset$ sten og Asia, mens den forholder seg relativt stabil (dog høyere enn for 30 år siden) i den vestlige verden. Dette kan skyldes at befolkningen $\mathrm{i}$ «den vestlige verden» har hatt lengre tid til å tilpasse seg «vestlig livsstil», på godt og vondt.

Det er grunn til å tro at hungersnød, paradoksalt nok, først ble en betydelig seleksjonsfaktor etter fremveksten av jordbrukssamfunn (24.). Jordbrukssamfunnet produserer riktignok mer mat enn de gamle jeger- og sankerkulturene, men gir større befolkningsvekst og urbanisering, dvs. en befolkning med mindre evne til selvforsyning. I et slikt samfunn gir feilslåtte avlinger økt risiko for hungersnød. Dette gir igjen en seleksjon i retning av fedme, hvilket passer godt inn i et urbanisert samfunn der behovet for fysisk aktivitet og mobilitet er lavere. Jegerkulturene på sin side unngår sult ved å leve på et mer variert kosthold, og i små mobile grupper, som kan forflytte seg til nye jaktmarker ved behov. De kan likevel ikke koste på seg en større fettmasse som de må transportere med seg. Dette kan forklare at enkelte grupper synes å ha mer «thrifty genes» enn andre. Kanskje er både jordbruks- og jegeradapsjonene representert i dagens befolkning? Det kan forklare kroppsvektsspredningen i den vestlige verden, som går hele veien fra slanke og normalvektige til overvektige, fete og morbid fete mennesker (25).

Hvis man tillater seg å se genetisk overlevelse i et gruppeperspektiv, ikke bare individuelt, vil et bredt spekter av ulike adapsjoner som er gunstige ved ulike typer av risiko, øke gruppens totale sjanse for overlevelse i en verden av ukjente farer, deriblant kaloriforgiftning. Dette kan også forklare et beslektet spørsmål: Hvorfor noen først får type 2-diabetes ved morbid fedme, mens andre får sykdommen ved normal kroppsvekt.

Manglende evne til å lagre fett øker risikoen for metabolsk sykdom hvis man lar kaloriene strømme fritt ( $\underline{26})$ ). Risikoen for kaloriforgiftning og type 2-diabetes handler ikke primært om kroppsvekt, men helsetilstanden på innsiden av kroppen. 


\section{LITTERATUR}

1. Neel JV. Diabetes mellitus: a «thrifty» genotype rendered detrimental by "progress»? Am J Hum Genet 1962; 14:353-62. [PubMed]

2. Huxley TH. Collected essays (1893-1894). VIII: Discourses: biological \& geological, biogenisis and abiogenisis. New York, NY: Georg Olms Verlag Hildesheim, 1970: 244.

3. Speakman JR, Westerterp KR. A mathematical model of weight loss under total starvation: evidence against the thrifty-gene hypothesis. Dis Model Mech 2013; 6: 236-51. [PubMed] [CrossRef]

4. Speakman JR. Thrifty genes for obesity, an attractive but flawed idea, and an alternative perspective: the 'drifty gene' hypothesis. Int J Obes (Lond) 2008; 32: 1611-7. [PubMed] [CrossRef]

5. Navarrete A, van Schaik CP, Isler K. Energetics and the evolution of human brain size. Nature 2011; 480: 91-3. [PubMed] [CrossRef]

6. Neel JV. Diabetes mellitus - a geneticist's nightmare. I: The genetics of diabetes mellitus. Berlin: Springer-Verlag, 1976:1-11.

7. Butler AE, Janson J, Bonner-Weir S et al. Beta-cell deficit and increased beta-cell apoptosis in humans with type 2 diabetes. Diabetes 2003; 52:102-10. [PubMed] [CrossRef]

8. Hoehn KL, Salmon AB, Hohnen-Behrens $C$ et al. Insulin resistance is a cellular antioxidant defense mechanism. Proc Natl Acad Sci U S A 2009; 106:17787-92. [PubMed] [CrossRef]

9. Barker DJ, Osmond C. Infant mortality, childhood nutrition, and ischaemic heart disease in England and Wales. Lancet 1986; 1:1077-81. [PubMed] [CrossRef]

10. Forsdahl A. Are poor living conditions in childhood and adolescence an important risk factor for arteriosclerotic heart disease? Br J Prev Soc Med 1977; 31: 91-5. [PubMed]

11. Vangen S, Nordhagen R, Lie KK. Gjensyn med Forsdahl-Barker-hypotesen. Tidsskr Nor Lægeforen 2005; 125: 451-3. [PubMed]

12. Hales CN, Barker DJ. Type 2 (non-insulin-dependent) diabetes mellitus: the thrifty phenotype hypothesis. Diabetologia 1992; 35:595-601. [PubMed] [CrossRef]

13. Barker DJ, Hales CN, Fall CH et al. Type 2 (non-insulin-dependent) diabetes mellitus, hypertension and hyperlipidaemia (syndrome X): relation to reduced fetal growth. Diabetologia 1993; 36: 62-7. [PubMed] [CrossRef]

14. Poulsen P, Vaag AA, Kyvik KO et al. Low birth weight is associated with NIDDM in discordant monozygotic and dizygotic twin pairs. Diabetologia 1997; 40: 439-46. [PubMed] [CrossRef]

15. Stöger R. The thrifty epigenotype: an acquired and heritable predisposition for obesity and diabetes? BioEssays 2008;30:156-66. [PubMed] [CrossRef]

16. Ravelli GP, Stein ZA, Susser MW. Obesity in young men after famine exposure in utero and early infancy. N Engl J Med 1976; 295:349-53. [PubMed] [CrossRef]

17. Heijmans BT, Tobi EW, Stein AD et al. Persistent epigenetic differences associated with prenatal exposure to famine in humans. Proc Natl Acad Sci U S A 2008; 105: 17046-9. [PubMed] [CrossRef]

18. Veenendaal MV, Painter RC, de Rooij SR et al. Transgenerational effects of prenatal exposure to the 1944-45 Dutch famine. BJOG 2013; 120: 548-53. [PubMed] [CrossRef]

19. Speakman JR. Evolutionary perspectives on the obesity epidemic: adaptive, maladaptive, and neutral viewpoints. Annu Rev Nutr 2013; 33: 289-317. [PubMed] [CrossRef]

20. Cypess AM, Lehman S, Williams $G$ et al. Identification and importance of brown adipose tissue in adult humans. N Engl J Med 2009;360:1509-17. [PubMed] [CrossRef]

21. van Marken Lichtenbelt WD, Vanhommerig JW, Smulders NM et al. Cold-activated brown adipose tissue in healthy men. N Engl J Med 2009;360:1500-8. [PubMed] [CrossRef]

22. Bakker LE, Boon MR, van der Linden RA et al. Brown adipose tissue volume in healthy lean south Asian adults compared with white Caucasians: a prospective, case-controlled observational study. Lancet Diabetes Endocrinol 2014; 2: 210-7. [PubMed] [CrossRef]

23. Diamond J. The double puzzle of diabetes. Nature 2003; 423: 599-602. [PubMed] [CrossRef]

24. Prentice AM, Rayco-Solon P, Moore SE. Insights from the developing world: thrifty genotypes and thrifty phenotypes. Proc Nutr Soc 2005; 64: 153-61. [PubMed] [CrossRef] 
25. Prentice AM, Hennig BJ, Fulford AJ. Evolutionary origins of the obesity epidemic: natural selection of thrifty genes or genetic drift following predation release? Int J Obes (Lond) 2008; 32: 1607-10. [PubMed] [CrossRef]

26. Wang MY, Grayburn P, Chen S et al. Adipogenic capacity and the susceptibility to type 2 diabetes and metabolic syndrome. Proc Natl Acad Sci U S A 2008; 105: 6139-44. [PubMed] [CrossRef]

Publisert: 9. desember 2014. Tidsskr Nor Legeforen. DOI: 10.4045/tidsskr.14.0941

Mottatt 30.7. 2014 og godkjent 27.10. 2014. Redaktør: Erlend Hem.

(C) Tidsskrift for Den norske legeforening 2023. Lastet ned fra tidsskriftet.no 26. april 2023. 